\title{
Development of dry ports in Europe
}

\section{Judit Oláh}

Faculty of Economics and Business, Institute of Applied Informatics and Logistics, University of Debrecen, 4032 Debrecen, Hungary

Email: olah.judit@econ.unideb.hu

\section{Steffen Nestler}

Deutsche GVZ-Gesellschaft mbH, 28359 Bremen, Germany

Email: nestler@gvz-org.de

\section{Thomas Nobel}

Department Logistic Systems, Institute of Shipping Economics and Logistics, 28359 Bremen, Germany

Email: nobel@isl.org

\section{Mónika Harangi-Rákos and József Popp*}

Faculty of Economics and Business,

Institute of Sectoral Economics and Methodology,

University of Debrecen,

4032 Debrecen, Hungary

Email: rakos.monika@econ.unideb.hu

Email: popp.jozsef@econ.unideb.hu

*Corresponding author

\begin{abstract}
Many German dry ports have already been successfully established and positioned in the past; however, several questions may arise. Can they keep pace with latest standards? Can they maintain their strong capabilities or are there locations in Europe, of whose achievements German dry ports can still 'learn'? What impulses come in turn from the German dry ports? The aim of this study was to illustrate the international logistics landscape and furthermore to give recommendations for the successful development of macro logistics concepts in Europe. The European ranking of 2015 is based in terms of its methodology on the scientific assessments of the authors. Therefore, it is evident that the results for example with use of a different weighting of the 40 evaluation criteria can certainly lead to different ranking results. In comparison to the first European Ranking 2010, there is no change among the TOP 3 in the ranking 2015.
\end{abstract}

Keywords: logistics services; dry port; macro logistics concept; hinterland; intermodal terminal; Europe. 
Reference to this paper should be made as follows: Oláh, J., Nestler, S., Nobel, T., Harangi-Rákos, M. and Popp, J. (2018) 'Development of dry ports in Europe', Int. J. Applied Management Science, Vol. 10, No. 4, pp.269-289.

Biographical notes: Judit Oláh is a $\mathrm{PhD}$ and an Associate Professor of the University of Debrecen Faculty of Economics and Business Institute of Applied Informatics and Logistics, Hungary. Her research interests are in logistics and supply chain management, operations management, transportation and warehouse management. Her research has appeared in the proceedings of national and international conferences and currently she has several manuscripts under review at journals.

Steffen Nestler is a Dipl-Ing and a Managing Director of the LUB Consulting $\mathrm{GmbH}$, a transport and logistics consultancy based in Dresden/Germany. For more than 20 years he has been involved in research and planning projects in intermodal transport and freight village development as well as sustainable city logistics. In addition, he is the Managing Director of the Association of German Freight Villages (DGG). He is a member of the German Association of Transport Sciences (DVWG) and of the German Logistics Association (BVL).

Thomas Nobel is Senior Project Manager at the Institute of Shipping Economics and Logistics Bremen (ISL) for more than 20 years. He focuses on research and consulting projects regarding logistics centres/freight villages, intermodality, city logistics as well as on sustainability and security in logistics. In addition, he is the Manager of the Association of German Freight Villages (Deutsche GVZ-Gesellschaft $\mathrm{mbH}$ ). He is a member of various national and international organisations and associations.

Mónika Harangi-Rákos holds a $\mathrm{PhD}$ and an Assistant Professor at the University of Debrecen, Faculty of Economics and Business, Institute of Sectoral Economics and Methodology, Hungary. She is an assistant of the Károly Ihrig Doctoral School of Management and Business. She wrote her PhD in the field of the change of economic roles of companies and individual farms, with special emphasis on animal husbandry. The main area of the scientific activity is international competitiveness and trade, management, food supply chain management, with special regard to sectoral analyses at the product path level.

József Popp is Professor at the University of Debrecen, Faculty of Economics and Business, Institute of Sectoral Economics and Methodology, Hungary. He is the Head of Károly Ihrig Doctoral School of Management and Business. He acted as a reviewer for several international journals and his research interests includes international agricultural policy analysis, competitiveness, rural development, supply chain management and bioenergy. He is also an active member and chairman of several academic and professional organisations and regularly conducts professional training seminars for various organisations.

\section{Introduction}

Current trends in maritime logistics often consider the presence of inland freight terminals where consolidation of goods, custom services, information processing activities, short-term storage and value-added manufacturing services for the containerised goods take place before shipment toward the next destinations (Crainic 
et al., 2015). An increase in sea freight flows generates an almost proportional increase in inland freight flows, and what takes place inland will influence the ability of intermodal transport systems to further accommodate the growth of international trade. This could be facilitated by dry ports, which have been developed to support seaport operations as well as the overall operations of intermodal transport systems (Hanaoka and Regmi, 2011; Rodrigue and Notteboom, 2012; Bask et al., 2014). The development of intermodal transport requires transport links, nodes, and services. The development of dry ports, an important component of intermodal transport, could play a major role in promoting intermodal transport (Hanaoka and Regmi, 2011). With the increase of containerised traffic, container terminals have started to develop in new locations in the hinterland of seaports (Korovyakovsky and Panova, 2011). Development of dry ports reduces customs costs, improves rail-sea intermodal capacity, and minimises transportation time $(\mathrm{Ng}$ and Cetin, 2012; Wang et al., 2016).

Now the port's potential hinterland can be defined as the area that can be reached at a cheaper cost or shorter time than from another port. As a result, hinterlands overlap. Therefore ports and carriage providers compete to service locations in these overlapping segments. With the advent of inland terminals, inland ports and dry ports, hinterlands are now extended even further inland, adding to the complexity of the analysis of port economics and logistics activities (Lee et al., 2008; Roso et al., 2009; Wilmsmeier et al., 2011). The management and expansion of the port hinterland is at the core of ensuring the competitiveness of modern ports (Shi and Li, 2016).

At the same time, port enterprises are paying more and more attention to the construction of dry ports (Li and Jiang, 2014). In addition to reduce the port's spatial and environmental pressure and to lessen the congestion of highway transport, the main purpose of a dry port is to extend the port hinterland by improving the facilities of the inland distribution centre, which closely integrate the maritime and inland freight depots (Shi and Li, 2016).

However, despite the emerging popularity of the dry port concept, very little research has been done on the assessment of development of dry ports in European countries. The goal of this paper is to support the transfer of positive effects on national and European level that are generated by dry ports on local and regional levels. The response to the first European ranking (2010), initiated by the Deutsche GVZ-Gesellschaft mbH (DGG), already showed the enormous interest of many dry port actors to get insights and information concerning market positioning and strategies of individual dry ports in Europe. Regarding the assessment of development of the dry ports in Germany and Europe, DGG conducts regularly extensive data collections. The collected data allows a profound overview of the status quo of the investigated dry ports (national or international) and allows the creation of a ranking to identify for example best practices.

\section{Review of literature}

\subsection{Locational characteristics of dry ports as a driving force for the development of local and regional economies}

One of the imperative issues of dry port development in developing economies is location planning. While the minimisation of set up costs and total logistics costs are key factors in dry port location analysis, there are also other more qualitative location factors driven 
by multiple stakeholders involved like operators, users and the community (Notteboom and Rodrigue, 2009; Nguyen and Notteboom, 2016). As a rule, the dry ports are located along the developed transport corridors (Panova and Hilmola, 2015). Dry port location planning requires a thorough decision making process as it is too costly to relocate the facility in the short term. Many models used for facility location attach a substantial role to transport costs in view of finding the optimal location (Nguyen and Notteboom, 2016). Usually located at strategic places near gateway seaports, industrial areas or along major transportation axes, dry port plays significant roles in optimising all activities to ensure cargoes can be delivered from one end to another in an efficient manner (Juhel, 1999). Furthermore, as proposed by (Azcárate, 2007), in the design of a methodology for location of an unwanted plant, a series of steps are carried out:

1 Exclusion phase: define a set of exclusion criteria.

2 Definition phase: the definition of a set of factors that allow us to measure the adequacy of the different places that have passed the previous restriction criteria.

3 Selecting assessment phase.

The results (Awad-Núñez et al., 2014) give greater importance to the aspects considered in the classical theories of industrial location. However, setting the most appropriate location to place a dry port is a geographical multidisciplinary problem with significant economic, social and environmental implications. Conventional notions of port choice have focused on geographical location as one of the main determinants of a port's attractiveness. The choice of a port is not merely a function of proximate convenience but derives considerable implications as well from the overall transit costs of cargo trafficking. For example, the distance between the port and the port user's premises has a major impact on inland transportation costs (Tiwari et al., 2003). In their surveys, (Willingdale, 1984, Murphy et al., 1991) found that the location factor had a relatively low ranking, yet they cited other studies, which have demonstrated that this is in fact a primary factor. One explanation they have given was that significant improvements in domestic transportation system appeared to have lessened the importance of close geographical proximity between ports and their customers in port choice decisions. Onut et al. (2011) reported that the main performance criteria of the port include geographic location and physical characteristics. Tovar and Rodríguez (2015) results show that use of a combination of cost frontier and cluster methods to define robust port typology and SOMs, jointly or in isolation, offers useful information to the decision-makers.

The Economic and Social Commission for Asia and the Pacific (ESCAP) has recognised the importance of dry port locations and suggests that the following criteria be considered when deciding upon a location:

a inland capitals, provincial/state capitals

b existing and potential industrial and agriculture centres

c major intersections of railways, highways, and inland waterways

d intersections along trunk railways lines, major highways, inland waterways, and at airports (Hanaoka and Regmi, 2011). 
Chang et al. (2015) suggest a cost-minimisation linear programming solution is proposed, with the aid of a genetic algorithm, to choose the optimal location as well as capacity level among the candidate inland cities.

However, while a number of research works investigating the locational characteristics and spatial dynamics of dry ports in Western, advanced economies exist (Rutten, 1998; Hesse, 2004; Hesse and Rodrigue, 2004; Roso, 2005; Rahimi et al., 2008; Notteboom and Rodrigue, 2009; Roso et al., 2009).

As far as investing in port assets is concerned, there are two ways, almost in contrast with one another, of regarding the port: The port may be considered a public service that is generally useful to the economy, justifying the tax system being utilised for the purpose of funding the investments required. The port may be considered a business system that operates within a highly competitive market and requires investment projects to be selected with efficiency. The line drawn between these two functions changes depending on the country, environment, business, social and political culture, and period and political trends (Musso et al., 2006).

The role of port as a driving force of the development of local and regional economies, both in developing (Omiunu, 1989), and developed countries (Witherick, 1981) is widely accepted by many scholars (Hilling, 2005; Ducruet, 2009). A large number of studies has shown that port activities (transportation, handling, storage, treatment and distribution) make ports of crucial importance for the development of regions where they are located (Deng et al., 2013) providing comparative advantages to them in terms of trade. However, several researches and studies which are carried out over time, place under contestation the local and regional benefits of ports (Gripaios and Gripaios, 1995) and their transport infrastructure, mainly for harbors sited away from economic regions (Malchow and Kanafani, 2004). Notteboom and Rodrigue (2005) in their research note the increasing regionalisation of ports and the gradual transfer of distribution centres towards the interior of the hinterland.

More particularly, the port function contributes to increased business activity, which is specialised in the shipping and transport services, while enhancing the business activity associated indirectly with this (banks, insurance companies, tourist agencies) (de Langen, 2004) and giving the opportunity to relevant stakeholders to invest (Dooms et al., 2015). Thus, dry ports in accordance with the above are catalysts of economic growth and employment creation (Jung, 2011) favouring the globalisation process.

\subsection{Development of dry port concept}

The dry port concept is based on moving of intermodal terminals further to hinterland from the port areas. It helps to avoid traffic bottlenecks, to connect cargo handling from the port with other types of cargo at one common transport centre and it can help develop the hinterland areas (Jaržemskis and Vasiliauskas, 2007). Dry ports in the original discussion were generally developed from the landside towards the sea, a requirement emerging from being landlocked or otherwise suffering from poor maritime access (Wilmsmeier et al., 2011). It was noted in the literature review that early dry port definitions referred to landlocked (or poorly-connected) countries using the terminal as a maritime access point. Since then, the term has been used in various ways, but without clear definition (Monios, 2011). 
In many places around the world bimodal and trimodal terminal facilities in the hinterland have become an intrinsic part of the transport system, particularly in regions having a high reliance on trade (Rodrigue and Notteboom, 2012). These nodes in the hinterland networks of seaports have been referred to as dry ports, inland terminals, inland ports, inland hubs, inland logistics centres, inland dry ports, inland clearance depots, inland container depots, intermodal freight centres and inland freight terminals (Cardebring and Warnecke, 1995; Wiegmans et al., 1999; Roso, 2005; Jaržemskis and Vasiliauskas, 2007; Notteboom and Rodrigue, 2009; Roso et al., 2009). Thus, there seems to be no consensus on the terminology used.

A recent academic definition of dry ports contends that for a fully developed dry port concept the seaport or shipping companies control the rail operations (Roso et al., 2009). Furthermore, the authors contend that dry ports are used much more consciously than inland terminals (Roso et al., 2009). Dry port, just as its name implies, is a concept we can contrast with water port. This term originated from Western countries in the twentieth century. The Council of Europe defined dry port as: a landlocked station which is connected to the seaport directly and geographically (Zhu, 2009). A dry port is a logistics node which improves cost-efficiency, environmental performance and the quality of hinterland network connections (Woxenius and Bergqvist, 2009; Cullinane and Wilmsmeier, 2011). This definition has been redefined as an extended container terminal gate (Törnquist and Gustafsson, 2004). Therefore this definition actually contradicts the original definition of a dry port, as it is driven from the seaward side. More recently, the term 'dry port' has been used in the industry as a marketing tool, perhaps to imply that an inland facility has reached a particular level of sophistication in terms of services offered, such as customs or the presence of third party logistics (3PL) firms within the site and/or an adjoining dry port or similar (see also GVZ in Germany, ZAL in Spain, interporti in Italy) (Wilmsmeier et al., 2011). But in Germany, dry port is usually referred to as inland cargo village. Dry ports, as nodes in transport networks, have been developed, among other reasons, to support seaport operations and the sustainable development of international intermodal transport chains, or links (Hanaoka and Regmi, 2011; Roso, 2013). Dry ports could make goods handling more efficient, and shifting freight volumes from road to rail (between port and dry port) could result in a lower environmental impact. In line with this, (Roso, 2013) claim that the construction of dry ports near strategic urban locations can help reduce the number of freight trips.

\section{Methodology}

The following elaboration outlines the results of the ranking in 2015. As part of the data collection in 2015 the DGG identified dry ports in 32 European countries. The ranking of the dry ports in 2015, as an outcome of the collected data, illustrates which dry ports in Europe could gain a very good performance due to a particularly successful development. As a basis of the creation of the current questionnaire, the questionnaire of the first European ranking 2010 conducted by the DGG, was used.

\subsection{Benchmarking partners and criteria}

Firstly, base of the study were considerations which logistics locations might be involved in the study. The main issue was here to verify the 'transferability' and so the use in the 
European context of the definition of the 'Bund-Länder-Grundsätze' of dry ports which was largely shaped by the DGG. A dry port is a building area where traffic commercial, logistics service providers, complementary service facilities and logistical industrial and commercial enterprises settle down as independent companies. A dry port is linked to several, but at least two transportation modes. A spatial split into functionally structured subareas is permitted. Due to the different forms of approaches in the various European countries, a direct transfer of the German definition is not possible. In order to achieve a high number of potential dry ports and to realise the widest possible analysis of national development levels, a broad interpretation was firstly selected, for that reason, also the 'dry port approach' was taken into consideration: based on (Roso, 2006).

A dry port is an inland intermodal terminal directly connected by road or rail to a seaport and operating as a centre for the trans shipment of sea cargo to inland destinations. In addition to their role in cargo trans shipment, dry ports may also include facilities for storage and consolidation of goods, maintenance for road or rail cargo carriers and customs clearance services (Beresford and Dubey, 1990; Jaržemskis and Vasiliauskas, 2007). The location of these facilities at a dry port relieves competition for storage and customs space at the seaport itself.

After the recording of nearly 300 locations in Europe the delivery of the questionnaire started in early 2015. The exact list was used later on as a basis for the assessments of locations and for the final creation of the ranking. The response rate was over $40 \%$ and almost all TOP dry port locations could be included in the final ranking.

Benchmarking is a process like this: first, select a representative enterprise in a certain industry, and then compare the research subject with the selected enterprise in several aspects (such as manufacturing, customer, distribution, management). Generally speaking, the main criterion for benchmarking is as follows: firstly, benchmarks should be enterprises with the best performance in the industry; secondly, benchmarks should be selected among competitors in the same industry and enterprises with similar functions and management (Li and Jiang, 2014).

The evaluation criteria are based on the criteria of the first European ranking 2010 (Koch et al., 2010). However, the evaluation criteria were extended from 29 to 40 (Table 1) and are no longer divided in 4, but 16 clusters (Figure 1).

Table 1 Evaluation criteria

\begin{tabular}{lc}
\hline Criterion number & Criterion \\
\hline 1 & Size of total area \\
2 & Exploitation in \% in relation to total area \\
3 & Current status of marketed area size in ha \\
4 & Opportunities expansion of space in ha \\
5 & Storage capacity in square meter \\
6 & Current number of companies \\
7 & Number of companies at final stage \\
8 & Current number of employees \\
9 & Final expansion of number of employees \\
10 & Employees per ha exploited area \\
11 & Time period between planning phase and first business settlement \\
12 & Year of complete development and marketing \\
\hline
\end{tabular}


Table 1 Evaluation criteria (continued)

\begin{tabular}{|c|c|}
\hline Criterion number & Criterion \\
\hline 13 & Decentralised/centralised dry port \\
\hline 14 & Greenfield/Brownfield \\
\hline 15 & Modality \\
\hline 16 & Number of the service facilities \\
\hline 17 & Market share of the total regional offered property \\
\hline 18 & Vacancy rate in $\%$ \\
\hline 19 & Personal estimation of level of development (own dry port) \\
\hline 20 & Number of employees of dry port development companies \\
\hline 21 & Range of tasks from management companies - amount \\
\hline 22 & Intensity of task (all estimations added and divided by the amount) \\
\hline 23 & $\begin{array}{c}\text { Transport mode: all assessments added and divided by the amount mode of } \\
\text { transport }\end{array}$ \\
\hline 24 & Positioning in TEN-T (amount) \\
\hline 25 & Terminal capacity in loading units \\
\hline 26 & Terminal utilisation in loading units \\
\hline 27 & Terminal utilisation in \% \\
\hline 28 & Terminal service offers - amount \\
\hline 29 & Green logistics: amount of the measures implemented \\
\hline 30 & $\begin{array}{c}\text { All assessments of the implemented measures added and divided by the } \\
\text { amount measures }\end{array}$ \\
\hline 31 & Security management: amount established measures \\
\hline 32 & Risks for the site (all assessments added by the amount) \\
\hline 33 & Strengths - amount \\
\hline 34 & Weaknesses - amount \\
\hline 35 & Opportunities - amount \\
\hline 36 & Threats - amount \\
\hline 37 & Modal traffic shift \\
\hline 38 & Urban logistics \\
\hline 39 & Green logistics \\
\hline 40 & Importance for the region \\
\hline
\end{tabular}

In order to guarantee the comparability of the European dry ports within the benchmarking process single samples were distinguished by processes. Processes in this context are to be understood as occupations that are preceded similar at various dry ports. As an example, the marketing strategy of the respective dry port can be mentioned. A second procedure is to make the processes comparable and more detailed based on the index. Basically absolute numbers are differentiated from ratio numbers.

First of all, a weighting of the benchmark criteria was created to evaluate the final ranking 2015. The basis of this weighting is the relevance of the respective criteria. The range of points is measured by 1 (low importance) to 6 (very high importance). Due to this grading, it is guaranteed that important criteria such as the current number of 
employees receive the appropriate attention in this ranking. In order to analyse the individual dry port location, the evaluation criteria were valued on a four-step scale from 0 to 3. A valuation of 0 indicates the lack of this feature in the dry port. A criterion valuated with 3 means a high importance for the dry port. Each criteria valuation represents different circumstances, resulting in differentiated definitions. In this context, exemplary characteristics are as follows: $0=$ not present, no relevance; $1=$ low, below average, at start of development; 2 = average; $3=$ high/large, above average, advanced; $4=$ (highest value in criterion number 17 'real estate').

Figure 1 Benchmarking clusters with evaluation criteria

\begin{tabular}{|c|c|c|}
\hline Intermodal terminal & & Green - logistics \\
\hline $\begin{array}{l}\text { Effects/contributions/ } \\
\text { importance }\end{array}$ & 16 cluster and & TEN-T \\
\hline Dry port - settlers & criteria & SWOT - analysis \\
\hline $\begin{array}{c}\text { Dry port - } \\
\text { characteristics }\end{array}$ & & Structural data \\
\hline $\begin{array}{l}\text { Task of the } \\
\text { development } \\
\text { companies }\end{array}$ & & Land and buildings \\
\hline $\begin{array}{l}\text { Connection to } \\
\text { transport } \\
\text { mode }\end{array}$ & & $\begin{array}{l}\text { Estimation of } \\
\text { development }\end{array}$ \\
\hline $\begin{array}{l}\text { Services of the dry } \\
\text { port }\end{array}$ & & $\begin{array}{l}\text { Development step of } \\
\text { dry port }\end{array}$ \\
\hline $\begin{array}{c}\text { Security } \\
\text { management }\end{array}$ & & $\begin{array}{c}\text { Structure of } \\
\text { developmnet } \\
\text { companies }\end{array}$ \\
\hline
\end{tabular}

As a reward for special advanced locations, so called 'Best in class', special points were awarded. To determine the score (performance) of a criterion, the valuation was multiplied by the weighting (Table 2).

Table 2 Criteria weighting (example cluster dry port settlements)

\begin{tabular}{lccc}
\hline Critetion number & Criterion & Weighting & Max. value \\
\hline 6 & Current number of companies & 3 & 3 \\
7 & Final expansion number of companies & 3 & 3 \\
8 & Current number of employees & 6 & 3 \\
9 & Final expansion of the number of employees & 4 & 3 \\
10 & Employees per ha exploited area & 3 & 3 \\
& & Max performance points \\
\hline
\end{tabular}


For the final ranking Table 2 of locations and the respective answers were joined with the weighted evaluation criteria. The individual value per criterion of each dry port was summed up at the end, so that each location earned a total score between 0 (minimum) and 380 (maximum).

\section{Results}

In the following chapter the results of the data collection (2015), which covers 90 dry ports, are presented and analysed. As explained in Section 2.3 they are divided into 16 clusters with each associated criteria. Parts (10 clusters) of the 16 clusters will be described in detail.

\subsection{Cluster 1}

To evaluate a dry port, key figures concerning the total area, storage capacity or notably, area expansion options are of particular importance. Also data concerning the development or marketing status (in ha) are of high interest for logistics properties. Implementation of a close dry port in a seaport's immediate hinterland increases seaport's terminal capacity and with it comes the potential to increase productivity since bigger container ships will be able to call at the seaport (Kovacs et al., 2008).

The average total area of the 90 dry ports in the ranking 2015 is ca. 180 ha of particular note is the size of Zaragoza PLAZA (Spain) with a total area of about 1,300 hectares, which is seven times as large as average. Among the German locations the GVZ Bremen (503 ha) and the GVZ Leipzig (640 ha) are significantly higher than the average European area size.

Under the criterion 'exploitation in relation to total area' the ratio of developed area/total area was observed. The average developed area in the European dry port is about 140 ha. Consequently, the developed area is close to $80 \%$ on average. Nevertheless, at some dry port the total area size is already completely developed, such as the GVZ Nuremberg, where the proportion of developed area is equal to the total area size (337 ha).

The marketing status was calculated in \% proportional to the developed area. It is notable that in many cases a marketing status of about $100 \%$ is already reached. Even in 10 German dry ports a value higher than $90 \%$ was determined. It is apparent that with an average marketing status of $80 \%$, the ratio from marketed area to developed area is generally high.

The ranking 2015 showed that many European dry ports have area expansion opportunities. On average the expansion area is about 60 ha. It should be noted that it is particularly difficult for dry port in conurbations to have sufficient space for expansion. In this regard for example dry port in Germany like GVZ Berlin and GVZ Nuremberg have nearly no potential for area expansion.

The average storage capacity of European dry port is approximately 260.000 square meters. Within this criterion, Plaza Zaragoza needs to be mentioned as 'Best in class' with a storage capacity of 4,270,000 square meters. The GVZ Bremen is in the second place with a capacity of 1,300,000 square meters, which is five times higher than the European average. Another remarkable feature is the storage capacity of Interporto Torino with a capacity of 900,000 square meters. 


\subsection{Cluster 2}

The current number of companies and the predicted number at final stage are important indicators for the development of European dry port. In addition to that, DGG included the current number of employees and the considered number of employees at final stage, to estimate the number of employees per hectare marketed settlement area. These numbers are becoming very helpful for the assessment of the resulting tax revenue and multiplier effects for the respective dry port region.

In 2015, the average number of companies in the European dry port was about 60 . The number of companies at final stage is estimated at an average of about 95 . Appreciable in Germany is GVZ Nuremberg with 260 established companies. 'Best in class' is with a current number of companies about 300 and 400 at final stage, Zaragoza Plaza in Spain.

The average number of employees in the European dry port is about 2.000. Within the TOP 5 of this criterion (6.500 - 13.000 employees) are two German dry ports. Quadrante Europa (Italy) as 'Best in class' has 13.000 employees.

The final stage of number of employees in Europe is on average 3.800. The ranking 2015 showed that there are ca. 30 employees per one hectare developed area. This is an absolute average value that contains next to the variance between the 90 dry ports also the range in logistics usages. For example, in modern logistics facilities several hundred workers per hectare are employed, whereas in intermodal terminals the value is below 10 employees per hectare.

\subsection{Cluster 3}

To create a characteristic of single dry port in Europe, criteria such as the distinction between a 'central and decentralised dry port', the differentiation between 'greenfield and brownfield development' or as well the criterion 'modality' where included in the questionnaire developed by the DGG.

Central dry ports have a significantly higher overall performance within the ranking 2015 than decentralised dry ports. Reasons are among others the agglomeration economy and higher synergy effects. Approximately $20 \%$ of the included locations indicated a decentralised site structure. Overall, a clear trend towards a central dry port structure can be recognised in recent years.

The determination of the original area of the dry ports has shown that a minor part of dry ports $(16 \%)$ perform a "brownfield-development". The identification of the dry port-origin area has shown that only a small part of dry port is based on a 'brownfield-development', although it is considered more positive with a point of view of urban development and land use aspects. Over $40 \%$ of companies have performed a shared 'greenfield/brownfield' or pure 'greenfield development'.

When asked about the number of existing modes of transport, the report shows a significantly higher number of 'bi-modal' dry ports (64\%) as expected. Locations with three or more modes of transport represent $36 \%$ within the dry ports that made a statement on this criterion. 


\subsection{Cluster 4}

Nguyen and Notteboom (2016) claim that the demand for dry port services in the location is one of the most important concerns to investors. Its rating/score can be obtained from demand forecasts related to the dry port project. The investment and operating cost is another imperative criterion. In terms of cost factors, the model considers land cost, energy cost, labour cost and the cost to relocate the railway station for rail network accessibility. Another factor is the room for expansion at the site, here measured by the maximum area allocated to the project. The next criterion is the investment and operational climate, which is indicated by the banking environment, government support and existing competition in the area. They reflect the ease of doing business, economic governance and administrative management and reform of local government, or in other words, the interaction between investors/operators with government and local players. Available indices such as the provincial competitiveness index (PCI) can be used for rating this criterion. The last criterion of inter-project explains that some investments are made despite of their negative net project value if they generate positive inter-project effects for other projects (De Schepper et al., 2015).

Based on cluster 5 'services of the dry ports' the number of existing activities and service facilities of the European dry ports was considered in more detail. Types of service facilities offered or planned by the dry ports are for example filling stations, truck repair station, social facilities (as sanitation) or catering (e.g., restaurants or canteens). Impressive is the number of existing service facilities of the Italian Interporto di Nola, which has all requested services and thus for example also a temperature-controlled warehouse, waste disposal facilities and a staffing service agency.

Figure 2 Service facilities within the dry ports in Europe (selection)

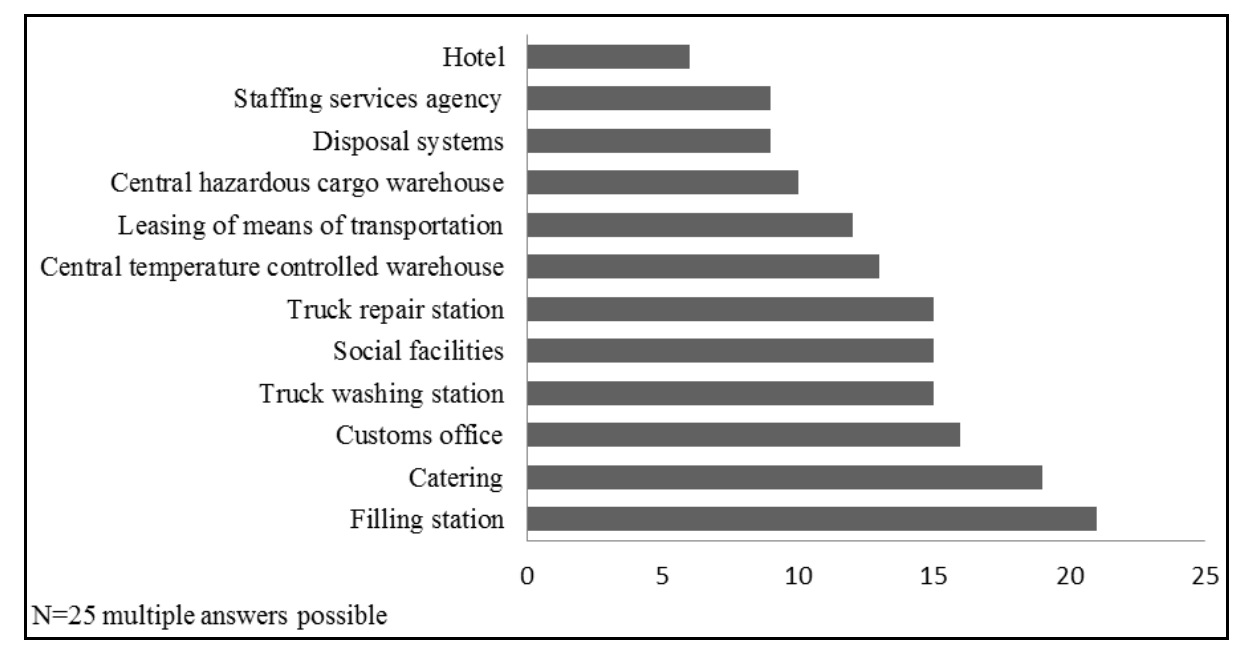

Looking at the range of services in the sum of European dry ports (Figure 2) it becomes clear that most of them contain catering offers, filling stations as well as a customs office. Truck repair stations and social services are also frequent. Need for expansion was identified in the field of truck wash and rental of transport equipment. 


\subsection{Cluster 5}

The development companies have estimated the level of development of the respective dry port in the respective country as well as in Europe. Figure 3 shows a comparison of the average assessment of level of development in Europe between the years 2010 and 2015. A clearly positive trend, especially in the estimation of level of development of the own dry port $(+1.2)$ can be recognised.

Figure 3 Stage of development compared 2010/2015

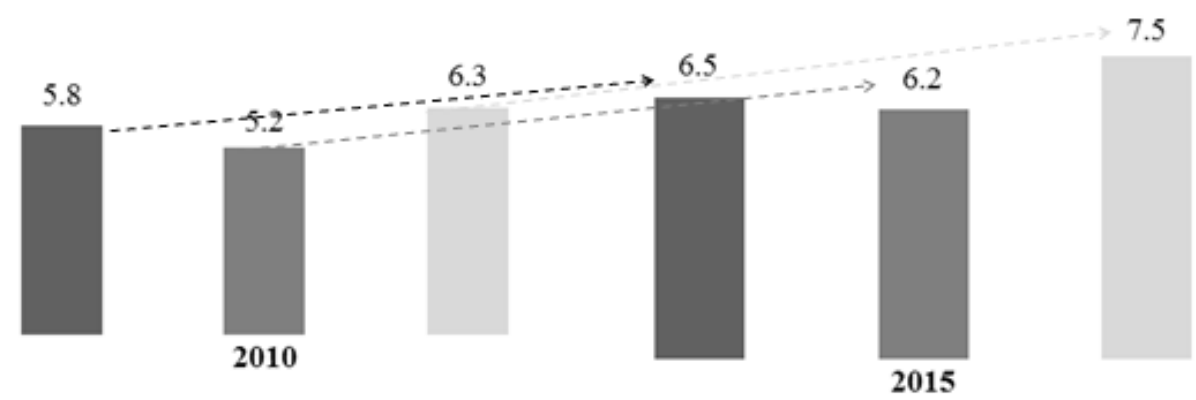

- Dry port stage of development - Europe

$=$ Dry port stage of development - own country

=Dry port stage of development - own dry port

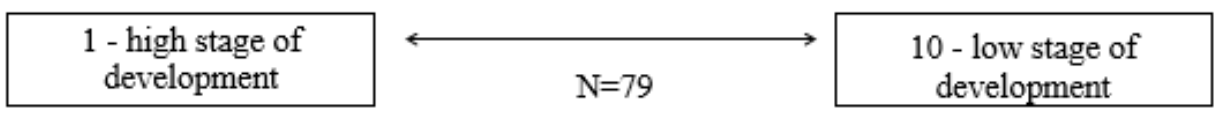

\subsection{Cluster 6}

During the further procedure, the offered activities by the development companies were considered in detail and its relevance was identified.

The range of activities by dry port development companies can be highly diversified and includes among others: support the planning process of the area, support the implementation process of the operating phase, acquisition of new tenants, location marketing (participation in trade fairs etc.), organisation of capacity balancing (e.g., joint use of energy, telecommunications, material etc.), further education and training offers (e.g., by seminars), logistics and consulting activities, cooperation in research projects, development and rental of logistics facilities.

In the consideration of the range of tasks the Italian Interporto Padova $\mathrm{SpA}$ is worth while mentioning this development company man ages beside the above-mentioned activities also City Porto, one of the major European City Logistics Services.

The relevance of the applied management activities and thus the activity intensity was examined by an own assessment by the dry port responsible person. In order to compare the intensity of tasks of the German dry port development companies with the European 
standards, a comparison with the Spanish and Italian dry port-development companies was made (Table 3 ).

Table 3 Intensity of tasks

\begin{tabular}{lccc}
\hline & $\begin{array}{c}\text { Average } \\
\text { Italy }\end{array}$ & $\begin{array}{c}\text { Average } \\
\text { Spain }\end{array}$ & $\begin{array}{c}\text { Average } \\
\text { Germany }\end{array}$ \\
\hline Supporting the planning process of the area & 9.6 & 9 & 9.4 \\
Acquisition of new tenants & 9.2 & 8.7 & 8.6 \\
Location marketing (participation in trade fairs, etc.) & 9.7 & 9.3 & 8.1 \\
Support of the implementation process/operating phase & 9.2 & 8.6 & 6.5 \\
Organisation of capacity compensation (for example, sharing & 7.9 & 6.7 & 5.2 \\
of energy, telecommunications, material etc.) & & & \\
Logistics-consulting activities & 7 & 6.3 & 4.9 \\
Cooperation in research projects & 8.1 & 3.2 & 4.9 \\
Development and rental of logistics facilities & 7.6 & 6.8 & 4.7 \\
Organisation of (further) training (for example through & 8.4 & 7.8 & 3.5 \\
seminars) & & & \\
Total average & 8.5 & 7.4 & 6.2 \\
\hline
\end{tabular}

Note: 1 - low task intensity; 10 - high task intensity.

As expected, it becomes visible that a strong focus in all three countries is to support the planning process of the area, the acquisition of new tenants and the location marketing. Especially the Italian dry port development companies (often owners of the dry port area and logistics facilities) put a great emphasis on supporting the implementation process and the operating phase. Moreover, it is remarkable that in Italy training offers receive a value above average.

\subsection{Cluster 7}

Inter-modality manifested by combined transport is of fundamental importance for dry ports. A trans-shipment facility is a defining characteristic for dry ports and a condition for an intermodal traffic network or rather for the realisation of combined transport (Koch et al., 2010).

To analyse the terminal capacity, the capacity of loading units (i.e., TEU converted into unit load) was indicated. This includes, for example, container, swap bodies and semitrailer. Imposing is the capacity volume of Interporto 'Quadrante Europa Verona' in Italy with $1,400,000$ loading units. Average in Europe is a terminal capacity of 150.000 loading units.

The terminal utilisation measured by the absolute number of loading units, is on average 75.000 loading units in the European dry ports. Taking also into consideration the utilisation of the sites, Quadrante Europa (Italy) with 700.000 loading units leads in Europe.

The terminal utilisation percentage was calculated in relation to the capacity and an average of little more than $50 \%$ was identified. However, six dry port sites, such as the GVZ Leipzig (Germany) or CLIP Logistics (Poland) have reached a utilisation level of approximately $100 \%$. 


\subsection{Cluster 8}

'Green logistics' provides opportunities for companies and the environment. For this reason, the European ranking 2015 includes strategies and processes from dry ports, which contribute to resource efficiently and eco-friendly logistics.

Figure 4 Measures for 'green logistics'

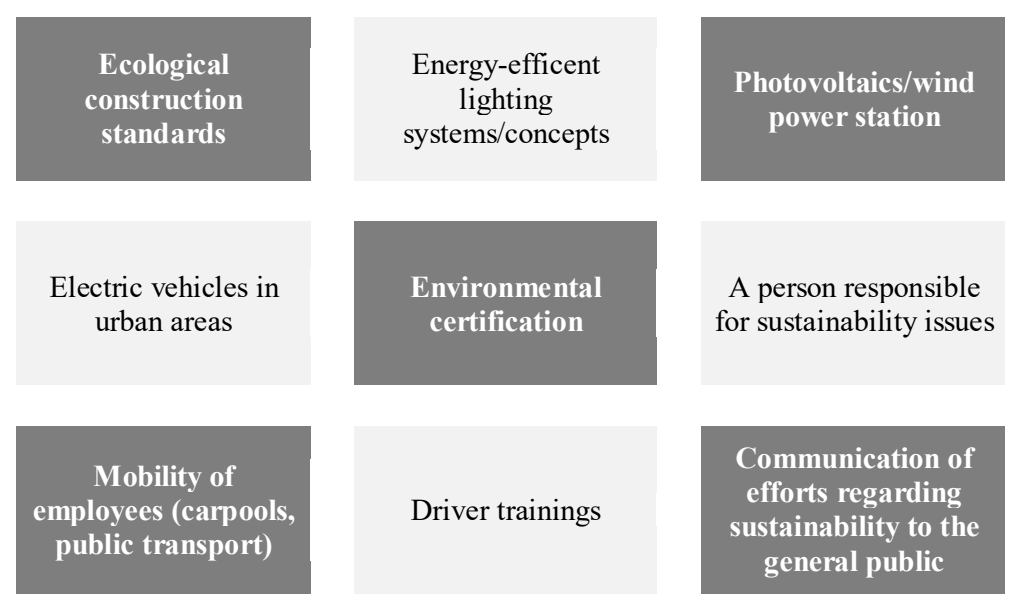

It should be mentioned that Merk (2012) with his research estimated that around $50 \%$ of the global shipping emissions are derived from the 25 largest ports in the world. Thus, in a large extent the negative port-city impacts depend on port size. A related report of the IMO (Smith et al., 2014) states that the international shipping is responsible for the production of $3.1 \%$ of global $\mathrm{CO} 2$ emissions. More specifically, the study by Miola et al. (2009) using data measurements estimated the externalities caused by the port operation in Venice city, while the study of $\mathrm{Ng}$ and Song (2010) were based on published data of the Port of Rotterdam to assess its overall environmental impact in the region.

Based on some examples the measures that have already been implemented by the dry ports were determined. Outstanding in the field of 'green logistics' is for example GVZ Nuremberg, which implemented all the measurements shown in Figure 4. - except the use of wind power station.

On the question, how many companies within the dry ports have implemented the above mentioned measures the answer was on average of 4.6 on scale of 0 (no companies) to 10 (all companies with high intensity). This shows that there is still need for action in the field of 'green logistics', even though some significant progress has been already achieved.

\subsection{Cluster 9}

The security management of the European dry ports was detected for the first time in more detail within the European ranking 2015. Here, the measures to increase the security level of dry ports as well as the biggest risks for dry port are considered in more detail. 
Measures that increase the security level of dry ports are for example: Physical security systems for the entire dry port area (e.g., fencing). Security system in form of entrance and exit gates. Security officer. Emergency plans (e.g., in case of flood).Almost half of the surveyed sites have established all the above mentioned measures. This can be observed particularly in the Southern European dry port, whereas German GVZ usually has no central gate.

An estimation of significant risks, as for example extreme weather events, accidents or terrorism was given during the further procedure. The majority of dry ports estimate these risks remarkably low. The estimation of the most significant risks for dry ports was given on a scale of 1 (Iow risk) to 10 (high risk). The average was about 3 . It is obvious that the estimation of risks varies greatly and that the risk of accidents or extreme weather events is considerably higher estimated in Germany than Italy and Spain. The probability of terrorism within the dry ports is measured in general relatively low.

\subsection{Cluster 10}

Finally, an assessment of effects, contributions and importance of the respective dry port was given. Based on a scale of 0 (no or very low) to 10 (very high), an evaluation about the criteria 'modal traffic shift', 'urban logistics', 'green logistics' and 'importance of the dry port for the region' was given.

Modal contributions of the modal shift from road to rail or inland waterway were rated with 8.0 on average. The modal shift is consequently one of the major 'brand cores' of the European dry ports idea.

The reduction of traffic in the urban area was estimated with 7.3 on average on a scale from 0 (very low) to 10 (very high). Occasionally the increasing activities of sites fall within the field of 'urban logistics'.

The importance of 'green logistics' was assessed lower than the 'urban logistics'. On average the European dry ports value topics like energy efficiency with a 6.4 on a scale from 0 to 10 . Nevertheless, this value is rather remarkable. Although in this case not only concrete measures, but also the spatial position of the dry ports plays a role.

\section{Conclusions}

The results of the empirical investigation demonstrated that the relative ranking of ports changes when measurements are taken into account simultaneously, both positive and negative effects of their operation, in relation to their respective position when considering only the one side of effects (Agallos, 2016). The benefits of port operation spread to a greater extent in the hinterland, indicating the significant importance of the location of a port in determining the port performance.

Several studies examine the general impact of the operation of ports (general impact assessment of port operations). In the methodological framework of these researches it is feasible to incorporate two important methods: the cost-benefit analysis (CBA) and the multi-criteria decision making analysis (MCDMA). These methods are used to evaluate ports regarding expansion projects, upgrades and construction of new port projects, taking into account both economic and environmental criteria (Agallos, 2016). The MDMA is based on an extended number of criteria that are used for the benchmarking of alternatives. In this category the studies written by Notteboom (2011) and Libardo and 
Parolin (2012) must be highlighted incorporating economic, social and environmental criteria in order to show off the most profitable port or project. However, the indicators that are used by each study to lead to the final result are significantly different.

Table 4 Total ranking of European dry ports

\begin{tabular}{lcc}
\hline TOP & Number & Description \\
\hline Top 20 & 1 & I - Interporto Quadrante Europa (Verona) \\
2 & D - GVZ Bremen \\
3 & D - GVZ Nürnberg \\
4 & D - GVZ Berlin Großbeeren \\
5 & E - Plaza Logistica Zaragoza \\
6 & I - Inrterporto Nola Campano \\
7 & I - Interporto Padova \\
8 & I - Interporto Bologna \\
9 & D - GVZ Leipzig \\
10 & I - Interporto Parma \\
11 & ES - ZAL Barcelona \\
13 & I - lnterporto di Torino \\
14 & H - BILK Logistics Centre (Budapest) \\
15 & I - Interporto Novara \\
16 & PL - CLIP Logistics (Swarzedz) \\
17 & F - Delta 3 Dourges (Lille) \\
18 & D - GVZ Berlin West Wustermark \\
20 & A - Cargo Center Graz \\
& & D - GVZ Südwestsachsen \\
& UK - DIRFT Daventry \\
\hline
\end{tabular}

In comparison to the first European ranking 2010, there is no change among the top 3 in the Ranking 2015 (Table 4). The top dry ports in Europe are: Interporto Verona, GVZ Bremen and GVZ Nuremberg. Interporto Verona, as one of the central dry port in Europe, took the lead due to a very good performance and so it is the first place in the ranking 2015.

There are some new placements within the TOP 20: GVZ Berlin Wustermark and GVZ Südwestsachsen. Six German dry ports gained a placement within the top 20. GVZ Leipzig (position 9) and GVZ Berlin (position 4) integrated themselves within the upper part of the ranking next to the already mentioned German dry port. Especially the GVZ Berlin Süd Grossbeeren improved in comparison to the first European ranking by some important positions. One reason is the high marketing dynamics. This is among other things due to the numerous logistics settlements in the context of the booming e-commerce (B2C) and the supply of consumer goods in the capital region. The German GVZ and the Italian Interporti are the leading dry ports in Europe and set the international performance standards. This is due to the high professional dry port development companies. The good position of the German dry ports is caused by the high impact on employment and the various area options. In addition, Spain is also one of the 
pioneers of the successful establishment of the dry port idea. A newcomer in the top 20 is CLIP Logistics (Poland) which demonstrates that the establishment of the dry port idea also made headway in Eastern Europe. This is confirmed by the positioning within the top 20 of BILK logistics centre (Budapest). Regarding intermodal terminals substantial research has been done on how to find the optimal location for inland intermodal terminals (Arnold et al., 2004).

How could be the ranking continued in the future? For example, the development of a worldwide 'rough'-ranking, based on only some criteria, could be projected. This global ranking could have as a result a notable visibility in the logistics community and in the corresponding media. It may be also interesting for port users and for business and institutions related to port industry.

The ranking of the dry ports is very important at policymaking level, as in this way good practices identified. Furthermore, the position of each dry port at the international level can be explained and understood as well. Consequently, it is necessary to construct indicators which use those data that will deliver the degree of sustainability of each dry port, while simultaneously will make the comparison between international ports feasible (Agallos, 2016).

\section{Acknowledgements}

Supported by the ÚNKP-17-4 New National Excellence Program of the Ministry of Human Capacities.

\section{References}

Agallos, I-C. (2016) The Contribution of Ports in Regional Development: Comparative Estimates via Indicator of Port Sustainability, Unpublished thesis, Athens University of Economics and Business.

Arnold, P., Peeters, D. and Thomas, I. (2004) 'Modelling a rail/road intermodal transportation system', Transportation Research Part E: Logistics and Transportation Review, Vol. 40, No. 3, pp.255-270.

Awad-Núñez, S., González-Cancelas, N. and Camarero-Orive, A. (2014) 'Application of a model based on the use of DELPHI methodology and multicriteria Analysis for the assessment of the quality of the Spanish dry ports location', Procedia-Social and Behavioral Sciences, Vol. 162, No. 19, pp.42-50.

Azcárate, M. (2007) 'Repercusiones sociales de una eficaz gestión de los residuos sólidos urbanos: un ensayo en el municipio de El Espinar (Segovia)', in Obra Social y Cultural de Caja Segovia, pp.149, Spain.

Bask, A., Roso, V., Andersson, D. and Hämäläinen, E. (2014) 'Development of seaport-dry port dyads: two cases from Northern Europe', Journal of Transport Geography, July, Vol. 39, pp.85-95.

Beresford, A.K. and Dubey, R. (1990) 'Handbook on the Management and Operation of Dry Ports, United Nations Conference on Trade and Development, Geneva.

Cardebring, P.W. and Warnecke, C. (1995) Combi-Terminal and Intermodal Freight Centre Development: An Assessment, Swedish Transport and Communications Research Board, Stockholm. 
Chang, Z., Notteboom, T. and Lu, J. (2015) 'A two-phase model for dry port location with an application to the port of Dalian in China', Transportation Planning and Technology, Vol. 38, No. 4, pp.442-464.

Crainic, T.G., Dell'Olmo, P., Ricciardi, N. and Sgalambro, A. (2015) 'Modeling dry-port-based freight distribution planning', Transportation Research Part C: Emerging Technologies, June, Vol. 55, pp.518-534.

Cullinane, K. and Wilmsmeier, G. (2011) 'The contribution of the dry port concept to the extension of port life cycles', in Handbook of Terminal Planning, Springer, New York.

de Langen, P. (2004) The perfoRmance of Seaport Clusters; A Framework to Analyze Cluster Performance and an Application to the Seaport Clusters of Durban, Rotterdam and the Lower Mississippi, Erasmus University Rotterdam, Rotterdam..

De Schepper, S., Haezendonck, E. and Dooms, M. (2015) 'Understanding pre-contractual transaction costs for Public-Private Partnership infrastructure projects', International Journal of Project Management, Vol. 33, No. 4, pp.932-946.

Deng, P., Lu, S. and Xiao, H. (2013) 'Evaluation of the relevance measure between ports and regional economy using structural equation modeling', Transport Policy, May, Vol. 27, pp.123-133.

Dooms, M., Haezendonck, E. and Verbeke, A. (2015) 'Towards a meta-analysis and toolkit for port-related socio-economic impacts: a review of socio-economic impact studies conducted for seaports', Maritime Policy \& Management, Vol. 42, No. 5, pp.459-480.

Ducruet, C. (2009) Port Regions and Globalization, Ashgate, Aldershot.

Gripaios, P. and Gripaios, R. (1995) 'The impact of a port on its local economy: the case of Plymouth', Maritime Policy and Management, Vol. 22, No. 1, pp.13-23.

Hanaoka, S. and Regmi, M.B. (2011) 'Promoting intermodal freight transport through the development of dry ports in Asia: an environmental perspective', IATSS Research, Vol. 35, No. 1, pp.16-23.

Hesse, M. (2004) 'Land for logistics: locational dynamics, real estate markets and political regulations of regional distribution complexes', Tijdschrift voor Economische Sociale Geografie, Vol. 95, No. 2, pp.162-173.

Hesse, M. and Rodrigue, J-P. (2004) 'The transport geography of logistics and freight distribution', Journal of Transport Geography, Vol. 12, No. 3, pp.171-184.

Hilling, D. (2005) Transport and Developing Countries London and New York, Taylor and Francis e-Library, Routledge, New York.

Jaržemskis, A. and Vasiliauskas, A.V. (2007) 'Research on dry port concept as intermodal node', Transport, Vol. 22, No. 3, pp.207-213.

Juhel, M H. (1999) 'The role of logistics in simulating economic development', in China Logistics Seminar, Beijing, 28-29 November 1999.

Jung, B-M. (2011) 'Economic contribution of ports to the local economies in Korea', The Asian Journal of Shipping and Logistics, Vol. 27, No. 1, pp.1-30.

Koch, H., Müch, S., Nestler, S. and Nobel, T. (2010) 'Ranking der europäischen GVZ-Standorte: Benchmarking der europäischen Erfahrungen', in Makrologistischen Knoten, Band 1, Wissenschaftlicher Verlag, Berlin.

Korovyakovsky, E. and Panova, Y. (2011) 'Dynamics of Russian dry ports', Research in Transportation Economics, Vol. 33, No. 1, pp.25-34.

Kovacs, G., Spens, K. and Roso, V. (2008) 'Factors influencing implementation of a dry port', International Journal of Physical Distribution \& Logistics Management, Vol. 38, No. 10, pp.782-798.

Lee, S-W., Song, D-W. and Ducruet, C. (2008) 'A tale of Asia's world ports: the spatial evolution in global hub port cities', Geoforum, Vol. 39, No. 1, pp.372-385. 
Li, J. and Jiang, B. (2014) 'Cooperation performance evaluation between seaport and dry port; case of Qingdao Port and Xi'an Port', International Journal of e-Navigation and Maritime Economy, December, Vol. 1, pp.99-109.

Libardo, A. and Parolin, A. (2012) 'Multicriteria analysis evaluating Venice port development', Procedia-Social and Behavioral Sciences, Vol. 48, pp.2545-2554.

Malchow, M.B. and Kanafani, A. (2004) 'A disaggregate analysis of port selection', Transportation Research Part E: Logistics and Transportation Review, Vol. 40, No. 4, pp.317-337.

Merk, O. (2012) 'Shipping-related emissions in world container ports: an overview', in International Forum on Shipping, Ports and Airports 2012 Conference Proceedings, Hong Kong Polytechnic University.

Miola, A., Paccagnan, V., Mannino, I., Massarutto, A., Perujo, A. and Turvani, M. (2009) External Costs of Transportation Case Study: Maritime Transport, JRC Scientific and Technical Reports.

Monios, J. (2011) 'The role of inland terminal development in the hinterland access strategies of Spanish ports', Research in Transportation Economics, Vol. 33, No. 1, pp.59-66.

Murphy, P., Daley, J. and Dalenberg, D. (1991) 'Selecting links and nodes in international transportation: an intermediary's perspective', Transportation Journal, Vol. 31, No. 2, pp.33-40.

Musso, E., Ferrari, C. and Benacchio, M. (2006) 'Port investment: profitability, economic impact and financing', Research in Transportation Economics, Vol. 16, pp.171-218.

Ng, A.K. and Cetin, I.B. (2012) 'Locational characteristics of dry ports in developing economies: some lessons from Northern India', Regional Studies, Vol. 46, No. 6, pp.757-773.

$\mathrm{Ng}$, A.K. and Song, S. (2010) 'The environmental impacts of pollutants generated by routine shipping operations on ports', Ocean \& Coastal Management, Vol. 53, No. 5, pp.301-311.

Nguyen, L.C. and Notteboom, T. (2016) 'A multi-criteria approach to dry port location in developing economies with application to Vietnam', The Asian Journal of Shipping and Logistics, Vol. 32, No. 1, pp.23-32.

Notteboom, T. (2011) 'An application of multi-criteria analysis to the location of a container hub port in South Africa', Maritime Policy \& Management, Vol. 38, No. 1, pp.51-79.

Notteboom, T. and Rodrigue, J-P. (2005) 'Port regionalization: towards a new phase in port development', Maritime Policy \& Management, Vol. 32, No. 3, pp.297-313.

Notteboom, T. and Rodrigue, J-P. (2009) 'Inland terminals within North American and European supply chains', Transport and Communications Bulletin for Asia and the Pacific, Vol. 78, No. 1, pp.1-39.

Omiunu, F.G. (1989) 'The port factor in the growth and decline of Warri and Sapele townships in the western Niger Delta region of Nigeria', Applied Geography, Vol. 9, No. 1, pp.57-69.

Onut, S., Tuzkaya, U.R. and Torun, E. (2011) 'Selecting container port via a fuzzy ANP-based approach: a case study in the Marmara Region, Turkey', Transport Policy, Vol. 18, No. 1, pp.182-193.

Panova, Y. and Hilmola, O-P. (2015) 'Justification and evaluation of dry port investments in Russia', Research in Transportation Economics, September, Vol. 51, pp.61-70.

Rahimi, M., Asef-Vaziri, A. and Harrison, R. (2008) 'An inland port location-allocation model for a regional intermodal goods movement system', Maritime Economics \& Logistics, Vol. 10, No. 4, pp.362-379.

Rodrigue, J-P. and Notteboom, T. (2012) 'Dry ports in European and North American intermodal rail systems: two of a kind?', Research in Transportation Business \& Management, December, Vol. 5, pp.4-15.

Roso, V. (2005) 'The dry port concept-application in Sweden', in Logistics Research Network, September, Vol. 7-9, pp.379-382.

Roso, V. (2006) Emergence and Significance of Dry Ports, Chalmers tekniska högskola, Göteborg. 
Roso, V. (2013) 'Sustainable intermodal transport via dry ports - importance of directional development', World Review of Intermodal Transportation Research, Vol. 4, Nos. 2-3, pp.140-156.

Roso, V., Woxenius, J. and Lumsden, K. (2009) 'The dry port concept: connecting container seaports with the hinterland', Journal of Transport Geography, Vol. 17, No. 5, pp.338-345.

Rutten, B.J. (1998) 'The design of a terminal network for intermodal transport', Transport Logistics, Vol. 1, No. 4, pp.279-298.

Shi, X. and Li, H. (2016) 'Developing the port hinterland: different perspectives and their application to Shenzhen Port, China', Research in Transportation Business \& Management, June, Vol. 19, pp.42-50.

Smith, T., Jalkanen, J., Anderson, B., Corbett, J., Faber, J., Hanayama, S., O’Keeffe, E., Parker, S., Johansson, L. and Aldous, L. (2014) Third IMO GHG Study, Vol. 13, pp.15-29, London, UK.

Tiwari, P., Itoh, H. and Doi, M. (2003) 'Shippers' port and carrier selection behaviour in China: a discrete choice analysis', Maritime Economics \& Logistics, Vol. 5, No. 1, pp.23-39.

Törnquist, J. and Gustafsson, I. (2004) 'Perceived benefits of improved information exchange - a case study on rail and intermodal transports', Research in Transportation Economics, Vol. 8, pp.415-440.

Tovar, B. and Rodríguez, H. (2015) 'Classifying ports for efficiency benchmarking: a review and a frontier-based clustering approach', Transport Reviews, Vol. 35, No. 3, pp.378-400.

Wang, G.W., Zeng, Q., Li, K. and Yang, J. (2016) 'Port connectivity in a logistic network: the case of Bohai Bay, China', Transportation Research Part E: Logistics and Transportation Review, November, Vol. 95, pp.341-354.

Wiegmans, B.W., Masurel, E. and Nijkamp, P. (1999) 'Intermodal freight terminals: an analysis of the terminal market', Transportation Planning and Technology, Vol. 23, No. 2, pp.105-128.

Willingdale, M. (1984) 'Ship-operator port-routeing behaviour and the development process', in Hoyle, B.S. and Hilling, D. (Eds.): Seaport Systems and Spatial Change, pp.43-59, John Wiley \& Sons, New York.

Wilmsmeier, G., Monios, J. and Lambert, B. (2011) 'The directional development of intermodal freight corridors in relation to inland terminals', Journal of Transport Geography, Vol. 19, No. 6, pp.1379-1386.

Witherick, M. (1981) 'Port developments, port-city linkages and prospects for maritime industry: a case study of Southampton', Cityport Industrialization and Regional Development, pp.113-132, Pergamon Press, Oxford.

Woxenius, J. and Bergqvist, R. (2009) 'Hinterland transport by rail - comparing the Scandinavian conditions for maritime containers and semi-trailers', in The International Association of Maritime Economists Conference (IAME), pp.1-15.

Zhu, T.J. (2009) 'How can dry port promote open economy in the interior - a case of Lanzhou dry port project', China Business and Market, Vol. 12, No. 4, pp.62-65. 